\title{
BRPKM
}

Buletin Riset Psikologi dan Kesehatan Mental

http://e-journal.unair.ac.id/index.php/BRPKM

e-ISSN: 2776-1851

ARTIKEL PENELITIAN

\section{Pengaruh Efikasi Diri dan Penyesuaian Diri terhadap Stres Akademik pada Mahasiswa Masa Pandemi COVID-19}

\author{
IFAN MAULANA \& ILHAM NUR ALFIAN* \\ Fakultas Psikologi Universitas Airlangga
}

\begin{abstract}
ABSTRAK
Penelitian ini bertujuan untuk mengetahui pengaruh efikasi diri dan penyesuaian diri terhadap stres akademik pada mahasiswa masa pandemi. Perubahan saat pendemi tersebut menyebabkan mahasiswa mengalami stres akademik dan peneliti ingin mengetahui ada tidaknya pengaruh antara efikasi diri dan penyesuaian diri terhadap stress akademik. Stres akademik yang dikembangkan dari Sarafino and Smith dan faktor yang mempengaruhi stres akademik adalah salah satunya efikasi diri yang disusun oleh Bandura dan penyesuian diri menggunakan teori Baker. Partisipan dalam penelitian ini adalah mahasiswa yang sedang menjalani perkuliahan secara daring/online. Metode penelitian menggunakan tipe penelitian kuantitatif dengan alat pengumpulan data menggunakan survei melalui Google Form. Dalam menganalisis data menggunakan SPSS 25 for windows. Hasil analisis menunjukkan regresi menyebutkan bahwa terdapat $18,1 \%$ pengaruh secara bersamaan antara efikasi diri dan penyesuaian diri terhadap stres akademik. Sedangkan pengaruh antara efikasi diri terhadap stress akademik sebesar $68 \%$ dan penyesuaian diri terhadap stress akademik sebesar 10,8\%.
\end{abstract}

Kata kunci: efikasi, stres akademik, penyesuaian diri

\section{ABSTRACT}

This study aims to determine the effect of self-efficacy and adjustment to academic stress in students during the pandemic. Changes during the pandemic caused students to experience academic stress and researchers wanted to know whether there was an influence between self-efficacy and adjustment to academic stress. Participants in this study were students who were undergoing lectures online. The research method uses quantitative research type with data collection tools using a survey via google form. In analyzing data using SPSS 25 for windows. The results of the analysis showed that the regression indicated that there was an effect of $18.1 \%$ simultaneously between self-efficacy and adjustment to academic stress. Meanwhile, the effect of self-efficacy on academic stress was $68 \%$ and adjustment to academic stress was $10.8 \%$.

Keywords: academic stress, efficacy, self-adjustment

Buletin Penelitian Psikologi dan Kesehatan Mental (BRPKM), 2021, Vol. 1(1), 829-836

*Alamat kopartisipansi: Fakultas Psikologi Universitas Airlangga, Kampus B Universitas Airlangga Jalan Airlangga 4-6 Surabaya 60286. Surel: ilham.nuralfian@psikologi.unair.ac.id

Naskah ini merupakan naskah dengan akses terbuka dibawah ketentuan the Creative Common Attribution License (CC-BY-4.0) (http://creativecommons.org/licenses/by/4.0), sehingga penggunaan, distribusi, reproduksi dalam media apapun atas artikel ini tidak dibatasi, selama sumber aslinya disitir dengan baik. 


\section{PENDAHULUAN}

Pandemi Covid-19 saat ini merupakan ancaman kesehatan global, dengan kasus yang dikonfirmasi dan kematian yang tinggi. Pada tanggal 30 Januari 2020, Organisasi Kesehatan Dunia mengumumkan bahwa wabah Covid-19 merupakan keadaan darurat kesehatan masyarakat yang menjadi perhatian internasional karena menimbulkan risiko tinggi, terutama bagi negara-negara dengan sistem pelayanan kesehatan yang rapuh (Sohrabi dkk., 2020).

Dalam menghadapi dampak pandemi Covid-19, pihak berwenang sulit merumuskan kebijakan ekonomi. Serta terganggunya layanan transportasi akibat Covid-19 akan berdampak pada rantai pasokan produk pertanian (Rockett dkk., 2020). Selain di sektor ekonomi, transportasi dan pertanian, pandemi Covid-19 juga berdampak besar di sektor pendidikan. Menurut Abidah (2020), dampak penyebaran Covid-19 kini mulai masuk ke bidang pendidikan. Institusi pendidikan diharapkan tidak melakukan aktivitas seharihari, hal ini diharapkan dapat menekan penyebaran Covid-19.

Perubahaan pembelajaran tatap muka menjadi pembelajaran online. Sejak wabah Covid-19 di Indonesia, pemerintah telah melakukan banyak upaya untuk mengurangi penyebarannya. Salah satunya meminimalisir kontak fisik dengan menggalakkan gerakan social distancing yang dapat menyebarkan virus corona dari satu orang ke orang lain. Menurut Tracy dkk. (2011), penerapan jarak fisik (sering disebut jarak sosial) telah menyebabkan banyak negara mengubah perilaku mereka secara nasional. Pada tanggal 23 Maret, Administrasi Umum Pendidikan Tinggi mengeluarkan surat edaran kepada pimpinan perguruan tinggi mengenai situasi pembelajaran selama darurat pandemi Covid-19. Pembelajaran berbasis online di mana mahasiswa tetap bisa melakukan transfer ilmu meskipun tanpa ada tatap muka secara langsung dengan maksud pengendalian penyebaran epidemi Covid-19. Hasil belajar tersebut diharapkan menjadi karya nyata masyarakat dan negara, yang merupakan bagian dari memerangi pandemi dan meningkatkan kemampuan mahasiswa (Sudarsana dkk., 2020).

Peralihan dari pembelajaran tradisional ke pembelajaran jarak jauh atau pembelajaran online telah menyebabkan mahasiswa menghadapi berbagai kendala di antaranya stres akademik (Harahap dkk., 2020). Hambatan yang dihadapi mahasiswa seperti jaringan yang tidak ada, habisnya paket internet, pekerjaan rumah yang harus diselesaikan, dan tumpukan pekerjaan, berbagai persyaratan akademik yang harus dipenuhi oleh mahasiswa membuat mereka berada di bawah stres akademik.

Ketidakmampuan mahasiswa untuk beradaptasi dengan situasi ini membuat mereka tertekan. Stres akademik menurut Sarafino dan Smith (2012) merupakan suatu kondisi yang disebabkan oleh ketidaksesuaian antara kondisi biologis dan psikologis dalam menghadapi tuntutan lingkungan dan menimbulkan perasaan tegang dan tidak nyaman. Eryanti (dalam Barseli 2018) menjelaskan bahwa stres akademik adalah tekanan pada mahasiswa yang disebabkan oleh persaingan atau persyaratan akademik.

Hasil penelitian Rachmawati (2014) menunjukkan bahwa stres akademik dipengaruhi oleh self-efficacy dan berkorelasi negatif. Hasil penelitian Liu \& Lu (2011) menemukan bahwa 90\% partisipan penelitian mengalami stres akademik akibat ujian, nilai yang tidak memadai, pekerjaan rumah yang tertunda, pekerjaan rumah, suasana sekolah yang tidak berdaya, keyakinan dan kemauan untuk belajar. Sagita dkk. (2017) menjelaskan bahwa mahasiswa yang mengalami stres akademik seringkali dipengaruhi oleh keterampilan manajemen waktu antara pembelajaran dengan aktivitas lainnya. 
Hasil penelitian terbaru menunjukkan bahwa sebagian besar mahasiswa mengalami tekanan akademis selama pembelajaran jarak jauh selama pandemi COVID-19. Berdasarkan analisis data, penelitian menemukan bahwa rata-rata mahasiswa berada di bawah tekanan sedang.

Stres dapat menyebabkan seseorang tidak dapat belajar secara normal karena adanya keseimbangan antara beban tugas dan kemampuan menyelesaikan aktivitas. Hanya ketika situasi tertentu mengancam atau melebihi sumber daya internal atau eksternal mereka, individu akan menganggap situasi ini sebagai penyebab stress (Govaerts \& Grégoire, 2004). Hasil penelitian Khan, Altaf dan Kausar (2013) menunjukkan bahwa stres akademik berpengaruh signifikan terhadap kinerja mahasiswa. Mahasiswa yang belajar dalam waktu singkat dan menyelesaikan banyak tugas akan sangat memengaruhi nilai mereka.

Efikasi diri dianggap sebagai cara untuk mengurangi dampak stres dan dengan demikian mengurangi potensi stres akademik. Pengertian self-efficacy membuat mahasiswa percaya diri dalam melaksanakan aktivitas dan menyelesaikan tugas dengan benar dan optimal. Self-efficacy bersumber dari kemampuan pribadi yang memengaruhi cara berpikir, motivasi diri dan tindakan. Orang dengan self-efficacy tinggi akan mampu menyelesaikan pekerjaan atau mencapai prestasi (Gufron, N., \& Risnawati, 2014).

Self-efficacy (kemampuan diri) merupakan hal terpenting dalam dunia pembelajaran. Dalam dunia ini seseorang harus percaya pada kemampuannya dalam menghadapi masalah dalam belajar, karena seseorang dapat mengungkapkan ilmunya dan dengan mudah menyelesaikannya masalah melalui kemampuan tersebut (Bertenthal \& Boker, 1996).

Santrock (2008) mengemukakan bahwa penerapan konsep self-efficacy pada semua aspek prestasi belajar mahasiswa menunjukkan bahwa self-efficacy memengaruhi pilihan kegiatan mahasiswa yang dilakukannya. Oleh karena itu, semakin tinggi efikasi diri seseorang, semakin tinggi kepercayaan dirinya terhadap kemampuannya dalam menyelesaikan tugas.

Bandura (2000) menunjukkan bahwa self-efficacy adalah kepercayaan pada kemampuan untuk mengatur dan melakukan tindakan yang diperlukan untuk menghasilkan keterampilan tertentu. Pervin dalam Smeth (1994) menunjukkan bahwa self-efficacy mengacu pada kemampuan untuk memahami perilaku yang terkait dengan tugas atau situasi tertentu. Bandura (2000) menjelaskan lebih jauh bahwa self-efficacy adalah keyakinan seseorang pada kemampuannya untuk mengontrol semua peristiwa yang memengaruhi hidupnya.

Salah satu faktor lain yang memengaruhi stres adalah kemampuan individu untuk mengatur atau berinteraksi dengan lingkungan (Thompson, 2009). Menurut Kirkcaldy (dalam Wijono 2006) stres terjadi ketika seseorang memiliki tantangan, tekanan, beban, atau kebutuhan di luar kemampuannya untuk beradaptasi. Faktor yang memengaruhi stres adalah ketidakmampuan individu untuk berinteraksi dengan lingkungan. Pembelajaran berkelanjutan harus menjadi tugas mahasiswa, oleh karena itu, sebagai mahasiswa harus dapat menyesuaikan diri agar tidak menimbulkan stres.

Baker \& Siryk (1986) mengungkapkan bahwa bagaimana mahasiswa menyesuaikan diri selama di universitas, dapat menjadi landasan bagi kemampuan adaptasi mereka terhadap peristiwa-peristiwa berikutnya selama kehidupan mereka di perguruan tinggi. Menurut Nixon dkk. (2008), faktor yang menentukan seseorang mengalami stres adalah kemampuannya untuk beradaptasi dengan perubahan yang terjadi. Tekanan yang ditimbulkan oleh rangsangan adalah rangsangan yang terlalu kuat, di luar kemampuan mereka untuk beradaptasi, sehingga rangsangan menimbulkan tanggapan yang kontradiktif di luar kendali individu dan lingkungan. Berdasarkan uraian di atas, peneliti tertarik untuk 
mencari tahu pengaruh efikasi diri dan penyesuaian diri terhadap stres akademik mahasiswa pada mahasiswa di masa Covid-19.

\section{Desain Penelitian}

\section{METODE}

Penelitian ini menggunakan pendekatan kuantitatif. Penelitian kuantitatif merupakan penelitian yang digunakan untuk meneliti sebuah populasi atau sampel tertentu, pengumpulan data ini menggunakan instrumen penelitian analisis data yang bersifat kuantitatif atau statistic dengan tujuan untuk menguji hipotesis yang telah ditetapkan (Suryanto, Herdiana, \& Alfian, 2012). Tipe yang digunakan dalam penelitian ini adalah Eksplanatori.

\section{Partisipan}

Partisipan dalam penelitian ini adalah mahasiwa yang sedang mengikuti kuliah daring atau online. Setelah melakukan proses pengumpulan data berdasarkan kriteria, maka diperoleh partisipan sejumlah 647 orang. Namun, setelah dilakukan penyaringan data outlier didapatkan 446 partisipan. Pengumpulan data dilakukan dalam jaringan (daring) secara sukarela melalui Google Form.

Partisipan dalam penelitian ini akan menggunakan non probability sampling. Teknik ini digunakan jika tidak memiliki data atau pengetahuan tentang seberapa besar populasi yang harus diteliti. Peneliti menggunakan teknik dari Pallant (2005) dan diperoleh minimal sample sebanyak 66 partisipan. Untuk menguji hipotesis penelitian penulis menyebar skala kuisioner untuk memperoleh data dari partisipan dan mendapatkan sebanyak 647 partisipan dengan 413 partisipan yang memiliki jenis kelamin laki-laki dengan persentase $92.6 \%$ dan sebanyak 33 partisipan yang memiliki jenis kelamin perempuan dengan persentase $7.4 \%$. partisipan rentang usia dari 17 hingga 24 tahun dan didominasi oleh subjek yang memiliki usia 20 tahun yang mana sebanyak 104 partisipan dengan peresentase 23,3\%. Diikuti oleh subjek yang memiliki usia 21 tahun yang mana sebanyak 99 orang dengan peresentase sebanyak $22.2 \%$. Sementara itu, peresentase terkecil adalah pada angka $2 \%$ yaitu partisipan yang memiliki usia 17 tahun yang hanya berjumlah 9 orang.

\section{Pengukuran}

\section{Skala stress akademik}

Skala stres akademik dikembangkan oleh Majrika (2018) dengan menggunakan teori Sarafino dan Smith (2012). Alat ukur stres akademik yang dibuat mengacu pada aspek biologis dan psikososial (cognition, emotion, dan social behavior). Aitem dalam skala stres akademik ini terdiri dari 40 aitem. Pada skala stres akademik ini terdapat empat alternatif pilihan jawaban yaitu sangat setuju (SS), setuju (S), tidak setuju (TS), dan sangat tidak setuju (STS). Pemberian skor bergerak dari rentang nilai empat (SS) sampai dengan nilai satu (STS) pada aitem-aitem favorable yang digunakan. Skor maksimal dari skala ini sebesar 160 dan skor minimal sebesar 40. dengan koefisien reliabilitas yang cukup baik $(\alpha=.923)$.

Skala self-efficacy

Skala self-efficacy dikembangkan dengan menggunakan teori Bandura (2000) berdasarkan aspek magnitude, generality, dan strength. Pada skala self-efficacy ini terdapat empat alternatif pilihan jawaban yaitu sangat setuju (SS), setuju (S), tidak setuju (TS), dan sangat tidak setuju (STS). Pemberian skor bergerak dari rentang nilai empat (SS) sampai dengan nilai satu (STS) pada aitem favorable yang 
digunakan. Skor maksimal dari skala ini sebesar 120 dan skor minimal sebesar 30. dengan koefisien reliabilitas yang cukup baik $(\alpha=.917)$.

Skala penyesuaian diri

Alat ukur yang digunakan untuk mengukur variabel Penyesuaian diri adalah skala Student Adaptation to College (SACQ) yang disusun oleh Baker. SACQ merupakan alat ukur yang bersifat self-report sehingga informasinya dapat diperoleh langsung dari subjek atau responden, bukan melalui informan. Alat ukur ini terdiri dari 67 aitem beserta 9 respons yang terdiri dari pilihan jawaban mulai skala 1 (Sangat Tidak Sesuai) hingga skala 9 (Sangat Sesuai). dengan koefisien reliabilitas yang cukup baik $(\alpha=.882)$.

\section{Analisis Data}

Penulis menggunakan teknik analisa data regresi dengan bantuan apilakasi SPSS 25.0 for windows.

\section{HASIL PENELITIAN}

Hasil survei yang dilakukan oleh peneliti menemukan sebanyak 647 orang, namun setelah peneliti melakukan eliminasi terhadap data responden, subjek dalam penelitian ini yang sesuai berdasarkan kriteria yang diinginkan peneliti memiliki jumlah sebanyak 446 orang. 446 responden dengan persentase total sebanyak $100 \%$ dengan masing-masing jumlah yaitu 413 responden yang memiliki jenis kelamin laki-laki dengan persentase $92.6 \%$ dan sebanyak 33 responden yang memiliki jenis kelamin perempuan.

Data deskriptif yang dilakukan oleh penliti menemukan variable Efikasi Diri $(M=64.84, S D=8.515$ sedangkan untuk variabel Penyesuaian diri $(M=330, S D=32.967)$. Untuk variabel Stres Akademik $(M=104.09, S D=18.060)$.

Penelitian menggunakan uji regresi berganda dilakukan untuk menguji apakah variabel efikasi diri dan penyesuaian diri berpengaruh secara stimultan terhadap stres akademik. Nilai R2 sebesar 0,181 atau $18,1 \%$. Hal ini menungukan bahwa stres akademik dapat dijelaskan sebesar $18,1 \%$ oleh variabel independen efikasi diri dan penyesuaian diri sedangkan 81,9\% stres akademik dijelaskan oleh variabel lain di luar variabel penelitian ini. Serta semua variabel independen memiliki signifikansi kurang dari 0,05 yang berarti semua variabel independent berpengaruh terhadap variabel dependent.

\section{DISKUSI}

Penelitian ini bertujuan untuk menguji apakah terdapat pengaruh antara efikasi diri dan penyesuaian diri terhadap stres akademik pada mahasiswa yang sedang menepuh Pendidikan melalui daring/online. Sebelum dilakukan uji regresi, penulis melakukan uji korelasi untuk mengetahui arah dan kekuatan hubungan antar dua variabel yang diteliti. Peneliti menemukan adanya hubungan yang negative dan lemah pada efikasi diri pada stres akademik serta untuk penyesuaian diri pada stres akademik memiliki hubungan yang negative dan sedang. Yang berarti semakin tinggi penyesuaian diri dan efikasi diri maka stress akademik mahasiswa akan semakin rendah begitu juga dengan sebaliknya.

Setelah melakukan uji hubungan dengan pearson correlation untuk mengetahui arah hubungan antar variabel peneliti melakukan uji regresi untuk mengetahui pengaruh antar variabel. Berdasarkan hasil analisis regresi sederhana didapatkan hasil bahwa ada pengaruh yang signifikan efikasi diri dan penyesuaian diri terhadap stres akademik pada mahasiswa yang sedang menempuh pendidikan melalui daring/online. Efikasi diri dan penyesuaian sosial memiliki pengaruh sebesar $18.1 \%$ dan $81.9 \%$ lainnya

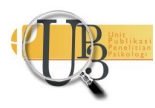


dipengaruhi oleh variable lain. Apabila dikaitkan dengan masa pandemi ini, mahasiswa membutuhkan efikasi diri dikarenakan efikasi diri yang tinggi akan membuat mahasiswa mampu menghadapi tekanantekanan yang terjadi selama pembelajaran daring, serta penyesuaian diri yang tinggi agar mahasiswa menyesuaikan diri dengan kebiasaan baru di tatanan pendidikan tinggi yang berbeda dengan budaya pembelajaran saat mereka di dalam perkuliahan. Penelitian ini didukung oleh penelitian yang dilakukan oleh PH, Mubin, \& Basthomi, (2020) menjelaskan bahwa selama pandemi Covid-19 mahasiswa mengalami stres dikarenakan stres akademik dan tugas perkuliahan yang diberikan. Saat ingin mengelola stres akademik ini sebelumnya kita harus tahu faktor-faktor penyebab stres dimasa pembelajaran secara daring ini.

Penelitian yang dilakukan oleh Hidayah dkk. (2020) mendukung hasil penelitian ini dimana stres mahasiswa selama pandemi sangat bergantung pada kemampuan mereka untuk beradaptasi dan menggunakan mekanisme koping untuk menghadapi metode pembelajaran yang baru. Kondisi stres yang dialami mahasiswa juga disebabkan oleh perubahan sistem pembelajaran, pekerjaan rumah memerlukan proses adaptasi yang baik, tentunya dalam menghadapi masalah baru mahasiswa harus menggunakan mekanisme koping yang tepat untuk mendukungnya. Bagi sebagian orang, proses penyesuaian tidak sulit dan mengancam karena hanya membutuhkan waktu yang singkat untuk beradaptasi dengan kondisi tersebut. Namun bagi yang lain, proses penyesuaiannya sulit dan butuh waktu lama untuk memicu stres individu (Anelia, 2012).

Limbong \& Simartaja (2020) menunjukkan bahwa efisiensi pembelajaran online mahasiswa tidak kurang efektif, dan selanjutnya menunjukkan bahwa 95,9\% siswa akan berada di bawah stres akademik yang dipengaruhi oleh faktor-faktor lain, seperti kemampuan manajemen waktu mahasiswa, keuangan. beban, interaksi dengan dosen, kegiatan sosial dan masyarakat. Hasil penelitian yang dilakukan menunjukkan bahwa mahasiswa yang melaksanakan kegiatan belajar pada saat pandemi Covid-19 dapat merubah diri untuk menyesuaikan diri dengan kebutuhan perubahan dan kondisi lingkungan selama masa pandemi.

\section{SIMPULAN}

Berdasarkan serangkaian hasil analisi yang telah dilakukan penulis, maka dapat disimpulkan bahwa efikasi diri dan penyesuaian diri secara signifikan berpengaruh terhadap stress akademik dan memiliki hubungan negatif antara variabel efikasi diri dan penyesuaian diri terhadap stress akademik yang berarti semakin tinggi efikasi diri dan penyesuaian diri maka akan semakin rendah stress akademik.

\section{UCAPAN TERIMAKASIH}

Alhamdulillah, puji syukur kehadirat Allah SWT karena atas berkat rahmat dan hidayahnya, penulis diberi kemudahan dan kelancaran dalam menyelesaikan skripsi dengan judul "Pengaruh Efikasi Diri dan Penyesuaian Diri Terhadap Stres Akademik pada Mahasiswa Masa COVID-19" sebagai salah satu prasyarat untuk memperoleh gelar Sarjana Psikologi Universitas Airlangga Surabaya. Penulis menyadari bahwa skripsi ini tidak akan selesai tanpa bantuan dan dukungan dari banyak pihak yang turut andil dalam proses pengerjaannya. Oleh karena itu pada kesempatan ini, penulis ingim menyampaikan terima kasih kepada pihak-pihak tersebut. 


\section{DEKLARASI POTENSI TERJADINYA KONFLIK KEPENTINGAN}

Ifan Maulana dan Ilham Nur Alfian tidak bekerja, menjadi konsultan, memiliki saham, atau menerima dana dari perusahaan atau organisasi manapun yang mungkin akan mengambil untung dari diterbitkannya naskah ini.

\section{PUSTAKA ACUAN}

Abidah, A., Hidaayatullaah, H. N., Simamora, R. M., Fehabutar, D., \& Mutakinati, L. (2020). The Impact of Covid-19 to Indonesian Education and Its Relation to the Philosophy of "Merdeka Belajar." Studies in Philosophy of Science and Education, 1(1), 38-49. https://doi.org/10.46627/sipose.v1i1.9

Anelia, N. (2012). Hubungan Tingkat Stres Dengan Mekanisme Koping Pada Mahasiswa Reguler Program Profesi Ners FIK UI Tahun Akademik 2011/2012. Universitas Indonesia.

Baker, R. W., \& Siryk, B. (1986). Exploratory Intervention With a Scale Measuring Adjustment to College. Journal of Counseling Psychology, 33(1), 31-38. https://doi.org/10.1037/0022-0167.33.1.31

Bandura, A. (2000). Exercise of human agency through collective efficacy. Current Directions in Psychological Science, 9(3), 75-78. https://doi.org/10.1111/1467-8721.00064

Barseli, M., Ahmad, R., \& Ifdil, I. (2018). Hubungan stres akademik siswa dengan hasil belajar. Jurnal EDUCATIO: Jurnal Pendidikan Indonesia, 4(1), 40. https://doi.org/10.29210/120182136

Bertenthal, B. I., \& Boker, S. M. (1996). Review of Thelen and Smith: A Dynamic Systems Approach to the Development of Cognition and Action. Contemporary Psychology, 41(10), 999-1001.

Govaerts, S., \& Grégoire, J. (2004). Stressful academic situations: Study on appraisal variables in adolescence. Revue Europeenne de Psychologie Appliquee, 54(4), 261-271. https://doi.org/10.1016/j.erap.2004.05.001

Gufron, N., \& Risnawati, R. (2014). PERBEDAAN BUDAYA DALAM KEPERCAYAAN EPISTEMOLOGI PERSONAL. EDUKASIA.

Harahap, A. C. P., Harahap, D. P., \& Harahap, S. R. (2020). Analisis Tingkat Stres Akademik Pada Mahasiswa Selama Pembelajaran Jarak Jauh Dimasa Covid-19. Biblio Couns: Jurnal Kajian Konseling Dan Pendidikan, 3(1), 10-14. https://doi.org/10.30596/bibliocouns.v3i1.4804

Hidayah, N., Muhammad Ikram, R., Sutria, E., Studi, P. S., \& UIN Alauddin Makassar, F. (2020). Tingkat Stress dan Strategi Koping Mahasiswa Keperawatan di Masa Pandemi Covid-19. Ojs.Unm.Ac.Id, 184-192. https://ojs.unm.ac.id/variansistatistika/article/view/19505

Khan, M. J., Altaf, S., \& Kausar, H. (2013). Effect of perceived academic stress on students' performance. FWU Journal of Social Sciences, 7(2), 146-151.

Limbong, T., \& Simarmata, J. (2020). Media dan Multimedia Pembelajaran: Teori \& Praktik. Yayasan Kita

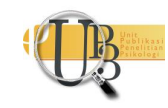


Menulis.

Liu, Y., \& Lu, Z. (2011). The Chinese high school student's stress in the school and academic achievement. Educational Psychology, 31(1), 27-35. https://doi.org/10.1080/01443410.2010.513959

Nixon, R., Menne, A., Kling, L., Steele, A., Barnes, J., Dohnt, H., Ball, S. A., \& Tyler, H. (2008). Metacognition, working memory, and thought suppression in acute stress disorder. Australian Journal of Psychology, 60(3), 168-174. https://doi.org/10.1080/00049530701867813

Pallant, J. (2005). SPSS SURVIVAL MANUAL: A step by step guide to data analysis using SPSS for Windows (Version 12).

Rockett, R. J., Arnott, A., Lam, C., Sadsad, R., Timms, V., Gray, K. A., Eden, J. S., Chang, S., Gall, M., Draper, J., Sim, E. M., Bachmann, N. L., Carter, I., Basile, K., Byun, R., O’Sullivan, M. V., Chen, S. C. A., Maddocks, S., Sorrell, T. C., ... Sintchenko, V. (2020). Revealing COVID-19 transmission in Australia by SARSCoV-2 genome sequencing and agent-based modeling. Nature Medicine, 26(9), 1398-1404. https://doi.org/10.1038/s41591-020-1000-7

Sagita, D. D., Daharnis, D., \& Syahniar, S. (2017). Hubungan Self Efficacy, Motivasi Berprestasi, Prokrastinasi Akademik Dan Stres Akademik Mahasiswa. Bikotetik (Bimbingan Dan Konseling: Teori Dan Praktik), 1(2), 43. https://doi.org/10.26740/bikotetik.v1n2.p43-52

Sarafino, E. P., \& Smith, T. W. (2012). Health Psychology: Biopsychosocial Interactions Ed. 7th. Jhon Wiley \& Sons.

Smeth, B. (1994). Psikologi Kesehatan. PT. Gramedia Widiasarana Indonesia.

Sohrabi, C., Alsafi, Z., O’Neill, N., Khan, M., Kerwan, A., Al-Jabir, A., Iosifidis, C., \& Agha, R. (2020). World Health Organization declares global emergency: A review of the 2019 novel coronavirus (COVID19). International Journal of Surgery, 76(February), 71-76. https://doi.org/10.1016/j.ijsu.2020.02.034

Sudarsana, I. K., \& dkk. (2020). COVID-19: Perspektif Pendidikan (Issue October).

Suryanto, A. M., Herdiana, I., \& Alfian, I. N. (2012). Pengantar Psikologi Sosial. Pusat Penerbitan dan Percetakan Unair.

Thompson, N. (2009). Stress. Promoting Workplace Well-Being, 12(03), 3-15. https://doi.org/10.1057/9780230274099

Tracy, M., Norris, F. H., \& Galea, S. (2011). Differences in the determinants of posttraumatic stress disorder and depression after a mass traumatic event. Depression and Anxiety, 28(8), 666-675. https://doi.org/10.1002/da.20838

Wijono, S. (2006). Pengaruh Kepribadian Type A dan Peran Terhadap Stres Kerja Manajer Madya. Jurnal INSAN, 8(3), 188-197. 